\title{
Regards
}

\section{Being in an environment: a performative perspective}

\author{
Andrew Pickering
}

Professor of Sociology and Philosophy, Dept of Sociology and Philosophy, University of Exeter, Exeter EX4 4RJ, United Kingdom

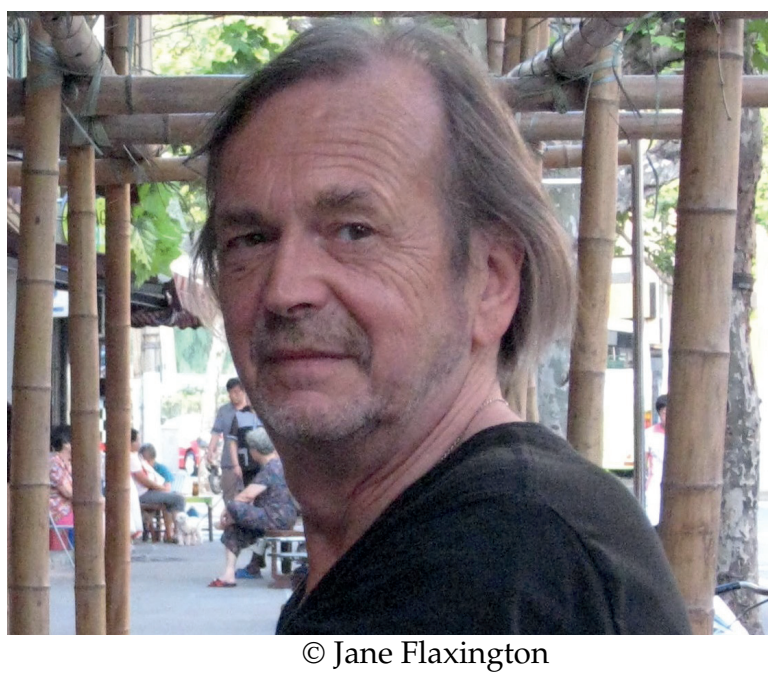

This essay lays out my general perspective on human relations with the environment ${ }^{1}$. The central thread is a conviction that our thinking on this topic should start from a concern with performance and agency - the actions of people and things - rather than from scientific knowledge as a given point of departure. My approach is ontological rather than epistemological. It grows out of my earlier work in science studies, and I begin by reviewing some concepts developed there, and why they clash with mainstream academic discourses, before moving on to environmental topics and examples. Key threads include a distinction between two paradigms in scientific and engineering approaches to the environment, and an attempt to put science in its place - to see

Auteur correspondant: a.r.pickering@exeter.ac.uk

1 This paper is a revised version of a talk given at Oxford University, 2 February 2012, as part of a series of Linacre Lectures on "Environmental Governance and Resilience". I am grateful for discussions at Oxford and to Laura Rival for the invitation to speak and her encouragement to revise the paper for publication.
Andrew Pickering was originally a physicist, with his first degree from Oxford and a PhD in particle physics from University College London. He changed fields to science and technology studies, joining the Science Studies Unit at Edinburgh University in the late 1970s. He taught for many years at the University of Illinois at Urbana-Champaign before returning to Britain as professor of sociology and philosophy at the University of Exeter. His books include Constructing Quarks: A Sociological History of Particle Physics (1984), The Mangle of Practice: Time, Agency and Science (1995) and, most recently, The Cybernetic Brain: Sketches of Another Future (2010). His current project, "Art and Agency", grew out of earlier research on cybernetic art.

from the outside just how science figures in our relations with the environment. I am especially keen to establish the possibility of engaging nature in a directly performative fashion - one that does not centre itself on knowledge, science and the laboratory.

\section{Science studies: performance and agency}

In 1995 I published a book called The Mangle of Practice: Time, Agency and Science, and all of my subsequent work has grown out of that. The analysis of scientific practice I laid out there was straightforward enough, but as I have taken the story further I have become increasingly aware of a mismatch between my thought and mainstream academic discourses. So one thing I need to do here is to clarify my position as well as I can, before addressing environmental questions.

The key move in The Mangle was to focus on performance rather than cognition. We have all been taught to think of science as primarily a cognitive activity - the production of knowledge about the world - but my 
argument was that if you want to understand scientific practice, you should start by thinking about (a) the performance of scientists - what scientists do; (b) the performance of the material world - what things do in the lab; and (c) how those performances are interlaced with one another. This might appear to be obvious: of course scientists struggle with the material world and try to come to terms with it. But actually, at least as far as the dominant academic traditions are concerned, it is not obvious. The natural sciences themselves tell us stories about how the material world is; the social sciences do the same for the human world; but neither of them talk about performative struggles between the two. There is a notable silence, a striking lack of systematic thought, on this topic. To that extent, western education continually reproduces a Cartesian cognitivism and a Cartesian dualism of people and things.

Now, it might be that there is a reason for this silence - namely, that there is nothing worth saying about performative interactions of people and things - but in The Mangle I did develop a few concepts that seemed to me to get somewhere, that broke the scholarly silence in ways that are worth taking further. One concept was "agency", a term that I use to refer directly to action, doing things that are consequential in the world. The key idea of The Mangle was that scientific practice has the character of a "dance of agency" between people and things, the human and the nonhuman. The first case-study in the book is about Donald Glaser's work in developing the bubble chamber as a new device for experimental particle physics. Very simply, along the way to the finished device Glaser built all sorts of set-ups; then he would stand back with a movie camera in his hand to record what they did; then he would react to that, somehow reconfiguring the set up; then he would see what that would do; react to that again; and so on. So this passage of practice is a nice example of a dance of agency. Sometimes Glaser acted as a classical human agent; then he would become passive and the apparatus took over the active role, doing its thing; then Glaser took over again, back and forth; and eventually a working bubble chamber emerged at the end.

This is simple and obvious - no-one has ever disputed that this is how things go in scientific research. But still, it is where my journey into academic outer space started. As I said, there is no room for talking about performative dances of agency within the mainstream disciplines. Importantly here, dances of agency are symmetric, they do not centre on or privilege the human. We are agents, but so are rocks and stones, cats and bubble chambers all of these things act and interact. And especially as far as the human sciences are concerned, symmetry is heresy. The human sciences play out a sort of "human exceptionalism" (Pickering, 2008a), dwelling endlessly upon what's so special about us: souls, mind, reason, language, representation, will, intentionality, values, etc, etc. Refusing this exceptionalism - refusing to centre the story on human specialness - is what first put me beyond the academic pale, I think (Pickering, 2009a).

One further remark and then we can move on. Agency, as I use the word, is emergent in practice in a brutal sense. Scientists cannot know how material set-ups will perform in advance-Glaser had to find out what his instruments would do by building them. Likewise, even Glaser himself did not know in advance how he himself would react to their performance - human agency is emergent too. That means that traditional causal interpretations of action are importantly misleading, and that we need to think instead about forward-looking evolutionary processes, dances of agency that explore a world of endless emergence and becoming. My story of the mangle was a way of trying to conceptualise that.

\section{From the lab to the world}

After writing The Mangle I began to think about ways of generalising the story beyond the lab (at the end of the book, I claimed it was a "theory of everything"). And I quickly realised that our relations with animals, nature and the environment are an obvious place to look. It might be hard to think about science along these lines we are so deeply conditioned to identify science with knowledge-but it is totally obvious that we engage with the environment performatively. In The Mangle I mentioned the weather, but think about earthquakes and tidal waves. How else could we regard these than as manifestations of the agency of nature, to which we react performatively, trying to ward them off, usually through engineering, but never quite succeeding?

And to bring this picture down to earth, I fixed on a couple of examples, which I can briefly discuss here. One was a story about invasive species, Asian eels in the midwest (Pickering, 2005). This was an amusing story I found in the New York Times, about the importation of these eels to the US as pets. They turned out to grow quickly and rather horrifyingly. The owners disposed of them in local ponds, where they multiplied and competed successfully for food with the fish. This upset the fishermen who liked catching large-mouthed bass, so various tricks were tried to get rid of the eels, for example draining the ponds. This didn't work because the eels survived by burrowing into the mud (unlike the fish, which died). Then people tried building concrete barriers to stop the eels spreading to other ponds and waterways - but this failed too because the eels just climbed over them.

For me, this is a beautiful example of a dance of agency, not now in the lab, but in the wild - a performative back and forth of the human and non-human in 
which the eels show up as always emergent, surprising, unpredictable. I want to ontologise it - to take it as a little model of how things go in the world in general. The world is full of agents which can interfere with one another consequentially but without any sense of control. We acted on the eels and made a difference for them, but the outcomes were not as hoped - they were emergent - and vice versa. All this seems to me visibly true, but one cannot say it in the language of mainstream ecology or sociology: they cut up and edit the world in ways that make it vanish.

After the eels, I fixed on the Mississippi, and John McPhee's wonderful history of the struggles between the river and the US Army Corps of Engineers - the ACE (Pickering, 2008b; McPhee, 1989). As McPhee tells it, this has been again a story of an emergent performative backand-forth. The river does something - floods - the ACE does something in response - raising the levees, building control structures - the river responds to that - running higher, washing away the structures - etc. Again, we have a dance of agency, now writ very large, in which the river, the engineering structures that surround it, and, indeed, the social groups and structures that depend on the river, have all been emergently and unpredictably transformed - mangled - over the past 150 years, or so.

What I take from this, then, is that there are interesting and possibly important things to say about our being in the environment in the performative idiom, as I call it, which are inexpressible in the language of the mainstream disciplines (civil engineering, hydrology, sociology, ecology). Thinking about dances of agency offers us what seems to me a new perspective on being in the environment, different from that of the conventional natural and social sciences.

\section{Science, emergence and islands of stability}

So what? Where does this get us? Let me follow a line of thought.

In the late 1990s, the University of Illinois where I then worked got a large grant to develop an interdisciplinary "capstone" undergraduate course to mark the start of the new millennium. I ended up co-organising it with David Ruzik, a colleague in the department of nuclear engineering. He taught the opening class, and he began by calculating the carrying capacity of the earth. You figure out the total amount of arable land there is, how much it can produce (with so much fertiliser, genetic engineering, and so forth) and divide by how much one person needs to live on. This gives you an estimate of the total population the earth can support. Ruzik's conclusion was that we do not need to worry for a while. This is not, of course, an unusual way to reason. The students had no difficulty with it and, in fact, it might be our usual way of thinking as far as global questions are concerned; it somehow exemplifies our usual way of "governing" the planet. But, at the time, I was dumbstruck by the hubris of it all, and now I can say why.

First, it ignores emergence. It assumes that we know all the chains of cause and effect, so that our initiatives will have the expected consequences, and only those. We grasp the levers of power through knowledge. Everything I know contradicts this - the story of Glaser and the bubble chamber; the eels; the ACE and the Mississippi. The world is too lively. We can interfere performatively with it, and it will respond, but there is no guarantee whatsoever that the response will be what we expect. Second, we could ask where emergence has gone in Ruzik's calculation. The answer is that conventional science substitutes for it, replacing a genuinely lively nature with machine-like representations that we can reason around. The levers of power are clear on paper, then, though not in the world. The same could be said of the Army Corps of Engineers. They too use the best of science in their dealings with the Mississippi; sometimes it works, sometimes it doesn't, and, sometimes, emergence breaks through, as in 2005 with Hurricane Katrina (Pickering, 2008a).

Where can we go now? One point that should be acknowledged, and that certainly needs more thought, is that, sometimes, we do manage to get on top of nature, so to speak. Machines do work reliably; roofs do keep the rain out. Usually, we think of this in representational terms. Engineers explain to us how bubble chambers or nuclear reactors work in terms of some known laws of nature, and we usually treat that as the end of the story. So, perhaps, one virtue of the turn to performance is to open the story up again. From my perspective, the production of reliable machines is not primarily a cognitive achievement at all; it depends, rather, on finding performative "islands of stability", as I call them, in intersections between the human and the non-human. These are not, in fact, given or guaranteed by knowledge; we should see knowledge as growing out of them. And they are chancy things. Our footing on them has to be continually adjusted, again in a performative fashion. Bubble chambers and nuclear power stations have to be serviced and maintained to keep them in shape, which once more takes the form of dances of agency. And we should recognise that sometimes we lose our footing. In the first generation of bubble chambers, the Harvard-MIT machine exploded, killing one person, injuring others and causing millions of dollars worth of damage. Fukushima evokes equivalent unexpected outcomes in the nuclear world (Pickering, 2012).

But the question I want to consider now is: does my story of dances of agency help us think about "other ways to go on" in the world, other ways to conduct our performances? I think it does. Our hegemonic way of engaging with the environment is the one I have just 
described - which Martin Heidegger (1977) called "enframing". It entails a detour, as Bruno Latour would say, through science. We turn the world into scientific representations, figure out how to dominate those, and then remake the world in line with our calculations. This detour, of course, is where emergence disappears and where things can go very wrong. What's the alternative? Skip the detour, forget about representations, forget about science; recognise instead that our being in the world is at root performative, and act that out.

We have now arrived in scholarly outer space. Words, language, symbols, representations, science - these are the stock in trade of us academics, and my recommendation is to forget about them - or, to speak in more measured terms, I want to put them in their place, to see them as a small part of a world of performance and becoming, by no means the centre of it. So I am not surprised when my colleagues look at me blankly when I say things like that. But we can press on. From a performative perspective, the key question is: what would this other way of going on - which Heidegger called "poiesis" and I like to call the stance of "revealing" - look like? Could we live without the detour through science and knowledge? Let me try to spin out some examples, in the spirit of an existence proof, moving from rather passive relations with nature to more active ones.

\section{Hylozoism}

I live in the Exe valley. You can see very easily where the floodplain of the Exe is, a flat strip of land a mile or so wide with the Exe meandering across it, hemmed in by nice Devon Hills, with their fields populated by cows and sheep. When the river floods, as it quite often does, the cows, sheep and farmers stroll off to higher land. There are a few more or less ancient raised tracks crossing the floodplain - walkways, railways, roadways - which look pretty odd and intriguing most of the time but whose purpose becomes totally obvious when the waters rise. We could say that over the centuries people in the Exe valley have found a way of living in dynamic equilibrium with the river; that this has involved very little by way of a detour through science; and that it works. The present configuration of the Exe valley is the upshot of the stance of revealing - a performative openness to what the river will do, and a performative response to that. The beautiful village I live in, a quasi-nomadic approach to farming, and the strange river architecture around it have all grown out of a long dance of agency.

Of course, the Exe is a little river, not so important in the grand scheme of things. The Rhine, on the other hand, is big and important, and it strikes me that the current Dutch project Room for Rivers is a revival of the traditional stance (Rohde et al., 2006; de Groot and Lenders,
2006; Palca, 2008). Room for Rivers aims, as I understand it, to let the river flood, in the spirit that it is better for us to adapt to regular finite floods than to try to pin down and enframe the river, with the disasters and catastrophes that inevitably follow. I am tempted to call Room for Rivers a "hylozoist" project. Hylozoism, for me, is the idea that everything we need is there in nature already, and that we can latch onto it directly and performatively instead of going through long detours of cognition for the sake of bending nature to our will. I started thinking about this when I was trying to understand the cybernetic biological computing projects of the 1950s and 1960s. There the truly amazing idea was to entrain pond ecosystems, for example, to manage factories (Pickering, $2009 \mathrm{~b}, 2010)$. Now it strikes me that water engineering in general might be moving in this hyolozoist direction - a realisation that maybe nature is better at controlling itself than we are.

These were examples of letting go; now I can turn to more active relations with nature. At a meeting in Oxford in December 2011 ("Practising Creativity: Thinking/ Making in the Act") Sarah Whatmore showed a picture of novel dams being built upstream of a Yorkshire town called Pickering (of all places!). The novelty of these dams is that they look as though they have been built by beavers rather than by engineers; they are simply tangled meshes of branches thrown across a stream. What fascinates me about them is that rather than dominating streams via a detour through science, they stage an exploratory dance of agency with them, finding out how nature will respond. Obviously, the state of the dams and how they act depends on their history, for example, on how much detritus has been washed down and caught by the dams or detached from them. I don't know how well they work, but this is an example of engineering in the mode of revealing and finding out, rather than enframing and domination through knowledge.

Moving from micro- to macro-structures, we could think about the Dujiangyan dam in China ( $\mathrm{Li}$ and $\mathrm{Xu}$, 2006). 2,000 years old, this dam is famous for the elegance of its performance. It acts differently according to the season and the waterflow in the river, variously diverting water into irrigation channels and dampening out floods. I have not been able to find out much about the history of the dam's construction, but it was not designed scientifically and its maintenance crucially entails a dance of human and nonhuman agency. The dam structure is not fixed; every year it is eroded by waterflows and every year it is rebuilt in line with the experience of the previous year. Not coincidentally, I think, it is one of the places where heaven and earth are joined - there always seems to be a spiritual angle on hylozoist relations to nature.

Staying in the east for a moment, we could think about the Chinese concept of shi. As the title of François Jullien's (1999) book explains, shi refers to the "propensity of 
things" to act in specific ways. The moral here is that successful human action depends on latching onto the shi of whatever situation one finds oneself in, going with the flow, in the Taoist sense of the term. I am told this way of thinking is simply commonsense in China, though it is certainly alien to western academic thought. What puzzles me about it is how one is supposed to know which way shi is flowing; what is the propensity of this arrangement or that? But thinking about this can move us towards consideration of some even more active ways of relating to the environment in the mode of revealing.

In his book, Seeing Like a State (1998), Jim Scott refers to a body of thought and action that he calls "metis", which he sees as a less poisonous alternative to modernist rationalisation. He gives an example that I find striking, of a traditional Japanese approach to the environment:

"Erosion control in Japan is like a game of chess. The forest engineer, after studying his eroding valley, makes his first move, locating and building one or more check dams. He waits to see what nature's response is. This determines the forest engineer's next move, which may be another dam or two, an increase in the former dam, or the construction of side retaining walls. Another pause for observation, the next move is made, and so on, until erosion is checkmated. The operation of natural forces, such as sedimentation and revegetation, are guided and used to the best advantage to keep down costs and to obtain practical results."

Clearly here, the engineer is finding out what the propensity of the valley and the water is, and he does that by deliberately staging a performative dance of agency with it: trying this, seeing what happens, trying something else, just like Glaser en route to the bubble chamber. So here we have a very nice example of a sort of purposeful finding out how to control nature without any detour though science and representation - a way of trading on the dance of agency rather than trying to short-cut it through knowledge. One point to emphasise, then, is that a performative perspective does not require us simply to let nature go its own way, as in the Exe valley; rather, it opens up the possibility of foregrounding and actively conjuring up emergent dances of agency in practice rather than casting a scientific veil over them. It might also be worth noting that one can speak of experiment in this connection: the Japanese forest engineer certainly experiments on water flows in the valley. But this is not the same sense of "experiment" as that usually associated with science. Scientific experiment depends on the detour I have been talking about: a displacement of phenomena away from the world and into the lab for the sake of producing knowledge which can then be re-exported to the world - which is, for example, how the Army Corps of Engineers proceeds in its dealings with the Misissippi. Scott's example points to another sort of experiment which entails performative interaction with the thing itself, with no displacement, and focused on a performative outcome rather than exportable knowledge - "experimentation in the wild", we could call it (following Hutchins, 1995).

Again, we can scale this example up, and also bring it more up to date. Lisa Asplen has written about performative and mangle-ish ways of getting along with the environment. The easiest one to think about is called adaptive management (Gunderson and Light, 2006). Just like the Japanese example, adaptive management, as I understand it, is all about experimentation in the wild and staging dances of agency as a way of exploring the shi of any given situation. Asplen (2008) discusses experimental floods on the Colorado River staged downstream from the Glen Canyon dam. The idea there was to find out how the river and the downstream ecosystem would react to different flows of water, as a basis for further dealings with them. One important point that Asplen emphasises is that while the scientists involved did have conventional scientific representations of river dynamics, they were prepared to find out that they were wrong - as indeed some of them were; valuable monitoring equipment simply got washed away; the river and ecosystem reconfigured themselves in ways that surprised the scientists. This sort of experimentation in the wild, then, is alive to emergence in the dance of agency, interested in it, not trying to short-circuit it through knowledge. Asplen (2008) also discusses projects of ecological restoration. These sound like classic enframing exercises, trying to make nature conform to a given representation of what it should look like. But what Asplen stresses is, again, that the restorers are alive to emergence, allowing their targets to shift in the light of what emerges in the dance of agency - a whole new ecological formation in the case she studied.

\section{Imagining another science}

That brings me to the end of my examples; where have we got to? From one angle, my basic idea is that we can understand the world as built from performative dances of agency. That is what there is in the world; that is my ontological vision. Then my idea is that we usually contrive not to see this. We edit out the emergent aspects of the dance by substituting scientific representations for them, and proceed to act on the basis of those representations. Like Heidegger, I think this is our characteristic way of inhabiting the world in modernity, in relating to the environment and much else. But a constructive spinoff of my analysis is that it helps us to imagine another way of being in the world - of experimenting directly in, and learning from, dances of agency, instead of conjuring them away via some epistemological sleight of hand. 
I have not dwelt on this, but I also think it is obvious from my examples that this other way of going on - the hylozoist stance of revealing - is, at least, much less prone to a catastrophic darkside than the stance of enframing and domination, which is something very much in its favour. From another angle, this essay is an attempt to argue that there are interesting and perhaps important things to be said in the performative idiom. As I mentioned before, I often feel like I have arrived in outer space, but I do not think it has to be outer space, even for academics. It should be our home, the place we set out from and return to in our explorations. To finish, perhaps I should explore a bit further how we should think about science itself.

I said earlier that we should get rid of science, but I immediately qualified that by saying I really wanted to put science in its place. What is going on here? We can start by thinking about the sort of conventional scientific knowledge that my friend David Ruzik used to calculate the carrying capacity of the earth. I feel like saying that we need more of this sort of knowledge but that we should trust it less. The worst thing we can do is forget about emergence by adopting a hard realist interpretation of current beliefs and putting them into practice come what may. I am afraid that is how we go on most of the time; I hope it is what environmental scientists are now realising does not work very well and simply invites disasters. Instead, we should see scientific knowledge for what it is - a situated, partial and retrospective way of making sense of what has happened so far. Cognitively, it may be the best we can do; it is our way of thinking about the future; but it is always liable to go wrong. Novelty will emerge from the dance of agency, and then we will, or should, revise our actions and beliefs. Practically, this means that when we try to act out our scientific visions we should be on the alert for surprises and willing to modify both our knowledge and our plans accordingly. Constant monitoring of worldly performance - this is what I mean by saying we should trust science less.

One of the cyberneticians I studied, Stafford Beer, once wrote a paper with a great title: "The Surrogate World We Manage" (Beer, 1975). His argument was that much management is totally focussed on a paper world of representations, and that the real-world consequences of this range from regrettable to catastrophic (think of the current so-called financial crisis). That is the sort of environmental management we need to beware of. And I could just mention that this always seemed a rather abstract point to me until I moved back to Britain in 2007. I now work in one of those surrogate worlds that Beer warned us about. I am sure the University of Exeter looks splendid on paper. You can actually find diagrams of reporting chains and flow charts on whiteboards in the administrators' offices. At the ground level, in contrast, we are all going mad trying to reconcile teaching and research with a stream of impossibly unrealistic commands. I imagine many rivers feel the same. Which, just to follow this tangent a bit further, reminds me of another cybernetician, Gregory Bateson. Bateson moved from an interest in schizophrenia in the 1950s to environmental concerns in the 1960s and 1970s, and he gave much the same analysis of both (Bateson, 1968; 2000). Both circle around attempts to stamp a modern blueprint onto an emergently lively system - enframing selves and rivers respectively - and the disastrous consequences that follow when these project fail. Hurricane Katrina as the madness of the Mississippi; madness as the Hurricane Katrina of the soul.

We can go back to science. I increasingly think it makes sense to distinguish between two different paradigms, in Kuhn's sense, for thinking about and acting in the world (Pickering, 2009b; 2010). One is the modern paradigm, exemplified here by Ruzik's calculations. As Heidegger said, this draws on the sort of science that makes the world calculable and sets it up for enframing. But there is a different kind of science, that Heidegger did not think about, which represents the world differently. Cybernetics would be one example of this other paradigm, but complexity theory is probably a more relevant version today. I am not an expert in this version of environmental studies, but I can sketch out some tentative thoughts.

First, I like the complexity approach a lot. Instead of linear models of cause and effect, it offers us a vision of basins of attraction in highly complex socio-ecological formations - attractors that pull these entities back to specific sorts of states, until one crosses a boundary when they flip over to another attractor, for better or for worse (Folke, 2006; Miller et al., 2010). This sounds to me like a much better representation of how the world is than calculations of the carrying capacity of the earth. And this sort of representation certainly serves as a warning against trying too quickly to edit out emergence and surprise. But two questions arise from a performative perspective. One goes back to the question of realism: should we just believe these sorts of representations: do they literally describe how the world is? In the world of Deleuzian philosophy, Manuel DeLanda (2002) would say yes to that question and then go on about attractors as the structure of "the virtual". I am inclined to say no. What complexity is good for is the construction of an alternative and non modern imaginary, for people who need that sort of thing. If you are a fan of science and would like to think your way out of enframing, read a few papers on complexity - they will show you how even a simple determinist world can nevertheless continually surprise us.

But from another angle, I am inclined to wonder what else complexity can do for us. I don't think there is much hope of ever pinning down the actual complexities of any important real ecosystem, of mapping the attractors and their boundaries; and I certainly don't think there is any hope of doing that for socio-ecological systems. Speaking ex cathedra as a sociologist, multi-agent models of social 
systems, for example, do not remind me of anything I have come across in my research. The social world is not built from $\mathrm{N}$ interchangeable and otherwise identical agents. At best, these models can function, again, as aids to the imagination.

In the end, what fascinates me is how necessary people find it to embark on incredibly long, complex, expensive and tiring detours through science to get hold of what sort of a place the world is. Why bother, when you simply have to look? Why is it so hard for us to see that we live in a world that just is lively and surprising? It probably starts with what we teach our children at school - but that is another story.

\section{References}

Asplen, L., 2008. Going with the flow: Living the Mangle in Environmental Management Practice, in Pickering, A., Guzik, K. (Eds), The Mangle in Practice: Science, Society and Becoming, Durham (NC), Duke University Press, 163-184.

Bateson, G., 1968. Conscious Purpose Versus Nature, in Cooper, D. (Ed.), To Free a Generation: The Dialectics of Liberation, New York, Collier, 34-49.

Bateson, G., 2000. The Roots of Ecological Crisis, in Steps to an Ecology of Mind, Chicago, University of Chicago Press, 496-501.

Beer, S., 1975. The Surrogate World We Manage, in Beer, S. (Ed.) Platform for Change: A Message from Stafford Beer, New York, John Wiley, 397-416.

de Groot, W., Lenders, H., 2006. Emergent Principles for River Management, Hydrobiologia, 565, 309-316.

De Landa, 2002. Intensive Science and Virtual Philosophy, London, Continuum Books.

Folke, C., 2006. Resilience: The Emergence of a Perspective for Socio-Ecological Systems Analyses, Global Environmental Change, 16, 253-267.

Gunderson, L., Light, S., 2006. Adaptive Management and Adaptive Governance in the Everglades Ecosystem, Policy Science, 39, 323-334.

Heidegger, M., 1977. The Question Concerning Technology, in The Question Concerning Technology and Other Essays, transl. W. Lovitt, New York, Harper \& Row, 3-35.
Hutchins, E., 1995. Cognition in the Wild, Cambridge (MA), MIT Press.

Jullien, F., 1999. The Propensity of Things: Toward a History of Efficacy in China, New York, Zone Books.

Li, K, Xu, Z., 2006. Overview of Dujiangyan Irrigation Scheme of Ancient China with Current Theory, Irrigation and Drainage, 55, 291-298.

McPhee, J., 1989. Atchafalaya, in The Control of Nature, New York, Farrar, Straus, and Giroux, 3-92.

Miller, F. et al., 2010. Resilience and Vulnerability: Complementary or Conflicting Concepts? Ecology and Society, 15, 3, [online].

Palca, J., 2008. In a Strategic Reversal, Dutch Embrace Floods, NPR, 22 January, www.npr.org/templates/story/story. php?storyId=18229027.

Pickering, A., 1995. The Mangle of Practice: Time, Agency, and Science, Chicago, University of Chicago Press.

Pickering, A., 2005. Asian Eels and Global Warming: A Posthumanist Perspective on Society and the Environment, Ethics and the Environment, 10, 29-43.

Pickering, A., 2008a. Against Human Exceptionalism. Paper presented at the workshop What Does It Mean to Be Human? University of Exeter, 25 January, http://hdl.handle.net/ $10036 / 18873$.

Pickering, A., 2008b. New Ontologies, in Pickering, A. Guzik, K. (Eds), The Mangle in Practice: Science, Society and Becoming, Durham (NC), Duke University Press, 1-14.

Pickering, A., 2009a. The Politics of Theory: Producing Another World, with some thoughts on Latour, Journal of Cultural Economy, 2, 197-212.

Pickering, A., 2009b. Beyond Design: Cybernetics, Biological Computers and Hylozoism, Synthese, 168, 469-491.

Pickering. A., 2010. The Cybernetic Brain: Sketches of Another Future, Chicago, University of Chicago Press.

Pickering, A., 2012. Ontological Politics: Realism and Agency in Science, Technology and Art, Insights, 4, www.dur.ac.uk/ ias/insights/volume4/article9.

Rohde, S., Hostmann, M., Peter, A., Ewald, K., 2006. Room for Rivers: An Integrative Search Strategy for Floodplain Restoration, Landscape and Urban Planning, 78, 50-70.

Scott, J., 1998. Seeing Like a State: How Certain Schemes to Improve the Human Condition Have Failed, New Haven (CT), Yale University Press. 